\title{
Akt mediated mitochondrial protection in the heart: metabolic and survival pathways to the rescue
}

\author{
Shigeki Miyamoto • Anne N. Murphy • \\ Joan Heller Brown
}

Published online: 18 April 2009

(C) The Author(s) 2009. This article is published with open access at Springerlink.com

\begin{abstract}
Cardiomyocyte death is now recognized as a critical factor in the development of heart disease. Mitochondria are not only responsible for energy production to ensure that cardiac output meets the body's energy demands, but they serve as critical integrators of cell survival signals. Numerous stressors are known to induce cell death by necrosis and/or apoptosis mediated through mitochondrial dysregulation. Anti- and pro-apoptotic Bcl-2 family proteins regulate apoptosis by controlling mitochondrial outer membrane permeability, whereas opening of the mitochondrial permeability transition pore (PT-pore) induces large amplitude permeability of the inner membrane and consequent rupture of the outer membrane. Akt is one of the best described survival kinases activated by receptor ligands and its activation preserves mitochondrial integrity and protects cardiomyocytes against necrotic and apoptotic death. The mechanisms responsible for Akt-mediated mitochondrial protection have not been fully elucidated. There is, however, accumulating evidence that multiple Akt target molecules, recruited through both transcriptional and post-transcriptional mechanisms, directly impinge upon and protect mitochondria. In this review we discuss mechanisms by which Akt activation can effect changes at the mitochondria that protect cardiomyocytes and attenuate pathophysiological responses of the heart.
\end{abstract}

Keywords Akt $\cdot$ Mitochondria $\cdot$ Heart $\cdot$ Hexokinase-II

S. Miyamoto $(\bowtie) \cdot$ A. N. Murphy $\cdot$ J. H. Brown Department of Pharmacology, University of California, 9500 Gilman Dr., La Jolla,

San Diego, CA 92093-0636, USA

e-mail: smiyamoto@ucsd.edu

\section{Introduction}

As a result of symbiotic invasion of eukaryotes by eubacteria more than 1.5 billion years ago, mitochondria have evolved to become the critical organelles for generation of cellular energy (Dyall et al. 2004) as well as gatekeepers in the control of cell survival (Kroemer et al. 2007). Heart tissue is amongst the most rich in mitochondria as there are profound energy demands on oxidative phosphorylation to support the beat-to-beat contraction/ relaxation cycle. Adult cardiomyocytes do not proliferate and accordingly their loss through cell death plays a crucial role in heart diseases involving ischemic injury and the development of heart failure (Adams et al. 2000; Dorn and Brown 1999; Gustafsson and Gottlieb 2008; Hayakawa et al. 2003; Murphy and Steenbergen 2008; Nakagawa et al. 2005; Nakayama et al. 2006; Scarabelli et al. 2006; Weiss et al. 2003; Yussman et al. 2002). It has become apparent in recent years that $\mathrm{Bcl}-2$ family proteins and the permeability transition pore (PT-pore) are important regulators of the mitochondrial death pathway that is activated by stress in cardiomyocytes (Gustafsson and Gottlieb 2008; Halestrap and Pasdois 2009; Murphy and Steenbergen 2008). The proapoptotic Bcl-2 family proteins induce mitochondrial outer membrane permeabilization (MOMP) (Reed 2008). Opening of the PT-pore at the inner membrane causes mitochondrial depolarization, the loss of small molecular weight substances from the matrix, and rupture of the outer mitochondrial membranes due to osmotic mitochondrial swelling (Baines et al. 2005; Crompton 1999; Crow et al. 2004; Green 2005; Green and Kroemer 2004; Gustafsson and Gottlieb 2003; Nakagawa et al. 2005; Weiss et al. 2003). The consequences of activation of these two pathways are reported to be different, and their interrelationship remains somewhat controversial. Bcl-2 family proteins are 
now believed to more specifically regulate apoptosis (Baines et al. 2005; Green 2005; Nakagawa et al. 2005). MOMP induced by apoptotic Bcl-2 family proteins leads to release of apoptotic molecules such as cytochrome c, leading to caspase-9/caspase-3 activation and DNA fragmentation. In contrast, the PT-pore is primarily associated with necrotic death (Baines et al. 2005; Nakagawa et al. 2005). Both apoptotic and necrotic cell death have been observed in the heart subjected to ischemic injury, in congestive heart failure and in cardiomyopathy, although the contribution of these two types of death is controversial and may differ depending on the types and pathological stages of stress. Regardless, preservation of mitochondrial integrity is essential not only to maintenance of metabolic homeostasis but also to survival of cardiomyocytes.

Protective signaling molecules are recruited in response to stress to prevent cell death. Akt is a serine/threonine kinase with well documented targets controlling diverse cellular functions, including protein synthesis, energy metabolism and cellular survival (Ceci et al. 2007; Fujio et al. 2000; Matsui et al. 1999; Matsui et al. 2001). Preservation of mitochondrial integrity has been shown to be involved in Akt-mediated protection (Lai et al. 2003; Miyamoto et al. 2008; Plas et al. 2001) and recent studies reveal that Akt has direct inhibitory effects not only on apoptotic Bcl-2 family proteins but also on the PT-pore (Ahmad et al. 2006; Davidson et al. 2006; Juhaszova et al. 2004; Miyamoto et al. 2008). Interestingly it is becoming increasingly clear that survival/death signaling and metabolic signaling share regulatory molecules as evidenced for example, by an unexpected physiological role of $\mathrm{BAD}$, an Akt target molecule, on glucose metabolism in $\beta$-cells (Danial et al. 2008). Other molecules recently reported as regulators of Akt mediated mitochondrial protection include glycogen synthase kinase 3 (GSK-3) and hexokinase-II. The mechanisms by which Akt confers mitochondrial protection in the heart will be discussed below.

\section{Cardiac injury, mitochondria and the PT-pore}

An increase in intracellular $\mathrm{Ca}^{2+}$ is responsible for normal cardiomyocyte contraction. In turn, mitochondrial $\mathrm{Ca}^{2+}$ increases in a beat-to-beat fashion in response to cytosolic $\mathrm{Ca}^{2+}$ transients and stimulates ATP production to meet energy demands via activation of $\mathrm{Ca}^{2+}$-sensitive matrix dehydrogenases (Maack and O'Rourke 2007; Szalai et al. 2000). It has been established that cardiomyocyte injury induced by ischemia/reperfusion ( $\mathrm{I} / \mathrm{R})$ results from increased cytosolic $\mathrm{Ca}^{2+}$ and generation of reactive oxygen species (ROS). As a result of loss of ionic homeostasis during ischemia, supra-physiological levels of cytoplasmic $\mathrm{Ca}^{2+}$ lead to mitochondrial $\mathrm{Ca}^{2+}$ overload during reperfusion. The combination of mitochondrial $\mathrm{Ca}^{2+}$ overloading, oxidative stress, and the loss of adenine nucleotides potentiates opening of the mitochondrial PT-pore (Crow et al. 2004; Gustafsson and Gottlieb 2003; Murphy and Steenbergen 2008; Weiss et al. 2003; Zorov et al. 2006). Recent genetic studies demonstrate that opening of the PTpore is also important in development of heart failure associated with dysregulated $\mathrm{Ca}^{2+}$ handling and $\mathrm{B}$-adrenergic receptor signaling (Nakayama et al. 2007).

The molecular entities that constitute the PT-pore remain elusive and controversial. Historically, the PTpore was believed to be composed of the adenine nucleotide translocase (ANT) in the inner membrane, the voltage-dependent anion channel (VDAC) of the outer membrane, and cyclophilin D (Cyp-D) in the matrix. This classic model has, however, been brought into question by recent genetic studies. Specifically, neither gene deletion and/or knockdown of VDAC or of ANT prevents PT-pore opening in response to mitochondrial $\mathrm{Ca}^{2+}$ overload (Baines et al. 2007; Kokoszka et al. 2004). A significant contribution of Cyp-D to PT-pore opening was first suggested by the inhibitory effect of cyclosporin A (Cs-A) on $\mathrm{Ca}^{2+}$-induced PT-pore opening detected as mitochondrial swelling (Crompton et al. 1988) and the subsequent discovery that Cs-A binds to Cyp-D (Tanveer et al. 1996). However, as Cs-A is also a potent calcineurin inhibitor, the mechanism of the profound cardioprotection from $\mathrm{I} / \mathrm{R}$ injury provided by Cs-A and the role of Cyp-D in pore formation remained ambiguous until recent studies of animals in which Cyp-D expression was genetically manipulated. It was then determined that mitochondria isolated from Cyp-D knockout mice are resistant to $\mathrm{Ca}^{2+}$ overload-induced PT-pore opening, and that Cyp-D null mouse hearts exposed to $\mathrm{I} / \mathrm{R}$ show significantly less injury than WT mice (Baines et al. 2005; Nakagawa et al. 2005). Conversely, mitochondria isolated from transgenic mouse hearts that express elevated Cyp-D show spontaneous pore opening (Baines et al. 2005).

While these genetic studies further defined the role of Cyp-D in PT-pore regulation, there remains controversy about the role of the PT-pore in apoptotic versus necrotic death. The knockout of Cyp-D has been reported to either have no effect on (Baines et al. 2005; Nakagawa et al. 2005), or to inhibit (Chiara et al. 2008) various forms of apoptotic cell death in vitro. The intriguing possibility that Cyp-D has a role in regulating apoptotic proteins in a manner that is independent of the PT-pore has recently been suggested (Eliseev et al. 2009), and this possibility has the potential to resolve some of the current conflicts in the field. 


\section{Cardiac injury and Bcl-2 family proteins}

Induction of the proapoptotic $\mathrm{Bcl}-2$ family proteins is a powerful mechanism for stimulating the mitochondrial apoptotic pathway. Bax and Bak, both proapoptotic members of the family, contain three Bcl-2 homology domains (BH-domain; $\mathrm{BH} 1, \mathrm{BH} 2$ and $\mathrm{BH} 3$ ), but lack a $\mathrm{BH} 4$ domain. The $\mathrm{BH} 4$ domain is critical for the protective effect of the anti-apoptotic Bcl-2 proteins (Chen et al. 2002) such as Bcl-2, Bcl- $\mathrm{X}_{\mathrm{L}}$ and Mcl-1. It has been suggested that $\mathrm{Bax}$ and $\mathrm{Bak}$ permeabilize the outer mitochondrial membrane by forming pores in response to apoptotic stimuli. MOMP induced by Bax/Bak is further activated in the presence of another class of proapoptotic Bcl-2 family proteins, the $\mathrm{BH} 3$-only proteins (BAD, BIM, BID, Bnip3, Nix/Bnip3L and PUMA) which facilitate Baxor Bak-mediated pore formation and/or antagonizing antiapoptotic Bcl-2 family proteins. The significance of Bcl-2 family proteins in cardiomyocyte survival and ischemic injury has also been established (Chen et al. 2002; Hochhauser et al. 2003; Kubli et al. 2007; Toth et al. 2006; Webster et al. 2005; Yussman et al. 2002). For instance, Bax deletion or Bcl-2 overexpression have been shown to protect the heart against ischemia/reperfusion (Brocheriou et al. 2000; Chen et al. 2001; Hochhauser et al. 2003). Expression of BNip3, a BH3-only protein, is induced by hypoxia and leads to apoptosis (Kubli et al. 2007; Webster et al. 2005) and Nix (BNip3L) is increased in hypertrophy and triggers apoptosis in the heart (Yussman et al. 2002). Ischemia/reperfusion-induced $\mathrm{Ca}^{2+}$ increases and subsequent activation of calpain can also lead to cleavage of Bid which induces cell death (Chen et al. 2002).

\section{Akt and cardioprotection}

Akt was originally described as an oncogenic protein and extensive studies have revealed that the activity of Akt is upregulated in many types of tumors, contributing to diminished apoptotic cell death and facilitating tumor growth. Akt regulates cellular metabolism, coordinated with its pro-survival and proliferative/growth effects. Akt is activated downstream of phosphatidylinositol 3-kinase (PI3K) in response to stimulation of receptor tyrosine kinases (Fujio et al. 2000; Matsui et al. 1999), glycoprotein 130(Craig et al. 2001; Kuwahara et al. 2000; Sheng et al. 1997) and G-protein coupled receptors (GPCRs) (Bell and Yellon 2003; Chesley et al. 2000; Cohen and Downey 2008; Downey et al. 2007; Means et al. 2007; Naga Prasad et al. 2000; Robert et al. 2001; Zhu et al. 2001) in the heart. Akt exerts a strong cardioprotective effect in response to activation of these receptors. Early studies using adenoviral gene transfer directly demonstrated that Akt protects heart against ischemia/reperfusion (Fujio et al. 2000; Matsui et al. 1999). Agonist induced Akt activation has also been demonstrated to be cardioprotective. For example, Akt is responsible for cardioprotection mediated by leukemia inhibitory factor (LIF) (Miyamoto et al. 2008; Negoro et al. 2001) or cardiotrophin-1 (CT-1) (Craig et al. 2001; Kuwahara et al. 2000), and Akt activation by insulin or S1P decreases $\mathrm{I} / \mathrm{R}$ damage within hours in the isolated perfused heart or in vivo (Jin et al. 2002; Jonassen et al. 2001; Means et al. 2007). It has been also suggested that Akt is involved in cardioprotection mediated by preconditioning, a series of brief cycles of $\mathrm{I} / \mathrm{R}$ prior to a sustained period of ischemia (Mocanu et al. 2002; Murphy and Steenbergen 2008; Tong et al. 2000; Uchiyama et al. 2004).

Diverse cellular Akt targets localized in various cellular compartments confer protection through transcriptional(Brunet et al. 1999; Cook et al. 2002; Craig et al. 2001; Muraski et al. 2007) and post-transcriptional regulation of pro-survival/pro-apoptotic proteins (Datta et al. 1997; del Peso et al. 1997; Kuwahara et al. 2000; Matsui and Rosenzweig 2005; Pap and Cooper 1998; Shiojima and Walsh 2006). Stimulation of receptors that activate PI3K results in an increase in $\mathrm{PIP}_{3}$; this drives Akt translocation to the plasma membrane where it becomes activated through phosphorylation at T308 by the upstream kinase, phosphoinositide-dependent kinase-1 (PDK1) and regulation at S473 by TORC2 (Sarbassov et al. 2005; Williams et al. 2000). In the cytosol, mTOR, GSK-3 $\beta$ and FOXO are phosphorylated by Akt, regulating translation, transcription and protein degradation (Matsui and Rosenzweig 2005; Morisco et al. 2000; Shioi et al. 2002; Skurk et al. 2005). It is now evident, however, that Akt activated at the plasma membrane is not only active in the cytosol but also translocates to subcellular compartments including the nucleus and mitochondria (Bijur and Jope 2003; Camper-Kirby et al. 2001; Kunkel et al. 2005; Miyamoto et al. 2008; Sasaki et al. 2003). Translocation of activated Akt to these subcellular components can mediate diverse effects. Redistribution of activated Akt to the nucleus and to mitochondria has been demonstrated not only by fractionation and immunostaining but also by using FRET-based Akt activity reporters in non-cardiac cells (Kunkel et al. 2005; Sasaki et al. 2003). Translocation of activated Akt to mitochondria was initially reported in neuronal cells (Bijur and Jope 2003), and we demonstrated similar translocation in cardiomyocytes stimulated by LIF, a glycoprotein 130 receptor agonist (Miyamoto et al. 2008). Preservation of mitochondrial integrity is known to be involved in Aktmediated protection (Lai et al. 2003; Miyamoto et al. 2008; Plas et al. 2001) and several target molecules through which Akt could afford mitochondrial protection have been identified. 


\section{Akt and mitochondrial protection through Bcl-2 family} proteins

Phosphorylation of Bcl-2 family proteins by Akt

Apoptosis is tightly controlled by $\mathrm{Bcl}-2$ family proteins through regulation of mitochondrial outer membrane permeability. BAD, a BH3-only apoptotic protein, was the first Bcl-2 family protein discovered to be phosphorylated and regulated by Akt (Datta et al. 1997; del Peso et al. 1997). Phosphorylation of BAD by Akt at Ser 136 promotes dissociation of $\mathrm{BAD}$ from $\mathrm{Bcl}-\mathrm{X}_{\mathrm{L}}$ a protective Bcl-2 family protein. Phosphorylation of BAD at Ser136 by agonists known to activate Akt has been demonstrated in the heart and correlated with cardioprotection (Aikawa et al. 2000; Jonassen et al. 2001; Kuwahara et al. 2000; Mehrhof et al. 2001; Negoro et al. 2001; Uchiyama et al. 2004). Another Bcl-2 family protein regulated by Akt is the proapoptotic BH1-3 protein, Bax which is a key molecule in mitochondrial outer membrane permeabilization. Phosphorylation of Bax by Akt at Ser184 leads to inhibition of the conformational change required for Bax translocation to mitochondria (Arokium et al. 2007; Gardai et al. 2004; Yamaguchi and Wang 2001). Phosphorylation of Bax at Ser184 has not been reported in the heart, but deletion of the Bax gene has been shown to decrease cardiac I/R injury (Hochhauser et al. 2003). An inhibitory effect of Akt on Bcl-2 family proteins has also been suggested to be involved in the protective effect of heat shock proteins (Hsp). Hsp27 was shown in an early study to associate with activated Akt (Konishi et al. 1997). This observation was extended by recent studies demonstrating that Hsp27, like Akt, inhibits Bax activation and apoptosis and that this occurs in a PI3K-dependent manner (Havasi et al. 2008). Hsp20 association with Akt was also recently shown to prolong Akt activity, leading to sustained phosphorylation of BAD in the heart (Fan et al. 2008).

Akt and expression of Bcl-2 family proteins

In addition to modulation of activity of pro-apoptotic proteins through phosphorylation, the expression level of Bcl-2 family proteins is regulated by Akt. For example, LIF treatment has been shown to work through a PI3K/Akt pathway to prevent the doxorubicin-induced decrease in Bcl- $\mathrm{X}_{\mathrm{L}}$ expression in cardiomyocytes (Negoro et al. 2001). Preconditioning (which activates Akt) has also been shown to prevent decreases in Bcl-2 expression level induced by I/ $\mathrm{R}$ (Uchiyama et al. 2004). Bcl-2 is also transcriptionally upregulated by IGF-1 through CREB in an ERK- and Aktdependent manner (Mehrhof et al. 2001). The mTOR complex-1 (mTORC1), which is downstream of Akt, controls expression of the anti-apoptotic Bcl-2 family protein Mcl-1 at the level of translation and promotes cancer cell survival (Mills et al. 2008). FOXO has three Akt consensus sequences and phosphorylation of FOXO by Akt facilitates its nuclear export and thereby inhibits its transcriptional activity. In non-cardiac cells, FOXO transcription factors are known to enhance expression of Bim, a BH-3 only protein (Dijkers et al. 2000; Gilley et al. 2003), although the significance of Bim and its regulation by Akt/ FOXO in cardiac pathophysiology has not been established. Taken together, there is abundant evidence that Akt exerts transcriptional, translational, and post-translational control of Bcl-2 family proteins which ensure that mitochondrial integrity is preserved against short-term and long-term stress.

\section{GSK-3 and Akt mediated mitochondrial protection}

Glycogen synthase kinase 3 (GSK-3) was initially described in the context of glycogen synthesis, but it is now recognized that this kinase contributes to regulation of many other cellular functions. GSK-3 functions in the heart as both a pro-apoptotic signal and as a suppressor of hypertrophic responses. There are two isoforms of GSK-3 (GSK-3 $\alpha$ and GSK-3 $\beta$ ); GSK-3 $\beta$ has been most extensively studied in the context of cardiac injury.

GSK-3 $\beta$ and Akt mediated phosphorylation

GSK-3 $\beta$ is an active kinase under basal conditions and Akt phosphorylation at Ser9 inhibits the kinase activity of GSK$3 \beta$. An earlier study by Murphy and co-workers demonstrated that preconditioning induces phosphorylation and inhibition of GSK-3 $\beta$ in a PI3K-dependent manner and that inhibition of GSK-3 $\beta$ by $\mathrm{LiCl}$ or pharmacological inhibitors mimics cardiac preconditioning against $\mathrm{I} / \mathrm{R}$ stress (Tong et al. 2002). Growing evidence suggests a proapoptotic effect of GSK-3 $\beta$ in the heart and demonstrates that inhibition of GSK-3 $\beta$ is involved in cardioprotection mediated by ischemic pre- and post-conditioning, as well as certain pharmacological interventions. Expression of a kinaseinactive form of GSK-3 $\beta$, acting as a dominant negative, protects rat ventricular myocytes from isoproterenol-induced apoptosis (Menon et al. 2007) and dominant negative GSK$3 \beta$ transgenic mice show well-compensated hypertrophy and reduced apoptosis and fibrosis during transverse aortic constriction (Hirotani et al. 2007). These findings demonstrate that inhibition of GSK-3 $\beta$ has beneficial effects in the heart and suggest the possibility that inhibition of GSK-3 $\beta$ by Akt-mediated phosphorylation at Ser9 could lead to cardioprotection. Indeed, a seminal study carried out using adult ventricular myocytes revealed that insulin inhibits ROS-induced PT-pore opening in a PI3K- 
dependent manner and this protection could be reversed by overexpression of GSK-3 $\beta$-S9A, a mutant that cannot be phosphorylated at Ser9 (Juhaszova et al. 2004). Sollott and co-workers also reported in this study that GSK-3 $\beta$ localized not only in cytosol but also at mitochondria. Phosphorylated GSK-3 $\beta$ has also been reported to be increased at mitochondria by agonists such as insulin (Juhaszova et al. 2004) and erythropoietin (Ohori et al. 2008), suggesting that Akt phosphorylates and inhibits GSK-3 $\beta$ actions at mitochondria. This hypothesis is supported by a recent study in which transgenic mice expressing GSK-3 $\beta$-S9A were utilized, to demonstrate that phosphorylation of Ser9 is required for Akt-mediated inhibition of PT-pore opening by post-conditioning in the heart (Gomez et al. 2008).

Recent evidence provides insights into molecular mechanisms by which inhibition of GSK- $3 \beta$ leads to mitochondrial protection. Using perfused heart and immunoprecipitation/ Western blotting, Nishimura et al showed that GSK-3 $\beta$, phosphorylated in response to preconditioning or erythropoietin treatment, interacts with ANT, leading to a decrease in association of ANT with Cyp-D and resultant protection (Nishihara et al. 2007). The precise mechanism by which GSK-3 $\beta$ inhibition exerts protective effects at mitochondria is controversial, however, as it has been suggested that postconditioning protects heart mitochondria through inhibition of GSK-3 $\beta$ in a Cyp-D-independent manner and that GSK$3 \beta$ actions occur upstream of the PT-pore (Gomez et al. 2008). A paper from Steenbergen's group proposed yet another model in which inhibition of GSK-3 $\beta$ during ischemia adapts mitochondria to ensuing reperfusion (Das et al. 2008). Their work indicated that GSK inhibitors prevent mitochondrial ATP consumption during ischemia and thereby protect mitochondria against subsequent reperfusion. This protective effect of GSK inhibitors was suggested to occur through decreased VDAC2 phosphorylation and inhibition of ATP transport into mitochondria. The authors proposed that the decrease in ATP hydrolysis by mitochondria during ischemia leads to lower mitochondrial membrane potential, which in turn lessens $\mathrm{Ca}^{2+}$ sequestration into mitochondria and consequent ROS generation during reperfusion (Das et al. 2008). Thus this metabolic adjustment induced by inhibition of GSK- $3 \beta$ may lead to prevention of mitochondrial $\mathrm{Ca}^{2+}$ overload and generation of ROS, two major inducer of the PT-pore.

Very recent studies by two different laboratories using GSK-3 $\alpha$ (S21A) and GSK-3 $\beta$ (S9A) knock-in mice suggest that the story is more complex. Matsuda et al. (2008) demonstrated that apoptosis induced by transverse aortic constriction (TAC) was inhibited by knock-in of GSK$3 \beta$ (S9A). They further tested the role of phosphorylation of GSK-3 $\alpha$ using a non-phosphorylatable mutant of GSK- $3 \alpha$ (S21A) which enhanced apoptosis during TAC. These results suggest that phosphorylation of GSK-3 $\beta$ at Ser9 is pro-apoptotic whereas that of GSK-3 $\alpha$ at Ser21 is protective (Matsuda et al. 2008). This is in sharp contrast to the observations obtained in GSK-3 $\beta$ (S9A) transgenic mice in which post-conditioning failed to protect the heart, leading to the conclusion that phosphorylation of GSK-3 $\beta$ at Ser9 is cardioprotective (Gomez et al. 2008). Another recent study demonstrated that pre-conditioning and post-conditioning protected the heart against I/R even in GSK-3 $\alpha(\mathrm{S} 21 \mathrm{~A})$ and GSK-3 $\beta$ (S9A) double knockin mice, suggesting that neither GSK-3 $\alpha$ nor GSK-3- $\beta$ phosphorylation at the known Akt sites are required for pre- and post-conditioning mediated cardioprotection (Nishino et al. 2008). Interestingly this study showed that insulin still preserves the ability to prevent the PT-pore in double knock-in mice, suggesting another target of Akt for PT-pore inhibition.

In summary it is currently unclear whether phosphorylation and inhibition of GSK-3 $\beta$ by Akt confers cardioprotection through inhibition of the PT-pore. The conflicting findings in the literature might reflect the use of different experimental models (e.g. acute inhibition by pharmacological inhibitors vs. chronic inhibition by overexpression of mutants of GSK-3; transgenic vs. knock-in mice), interventions to induce stress (TAC, ex vivo $I / R$ and in vivo $\mathrm{I} / \mathrm{R}$ ), and different methods for detection of the PTpore opening (e.g. mitochondrial membrane potential, mitochondrial swelling, calcium retention capacity).

\section{GSK-3 $\beta$ and Bcl-2 family proteins}

GSK-3 $\beta$ has been reported to directly regulate Bcl-2 family proteins. Mcl-1, an anti-apoptotic Bcl-2 family protein, was originally reported by Green and co-workers to be phosphorylated by GSK-3 and degraded, an effect that was prevented by Akt expression (Maurer et al. 2006). Upregulation of Mcl-1 by GSK inhibition has been recently reported to be protective against TNF- $\alpha$ in cardiomyocytes (Hirotani et al. 2007). In addition to the potential for control of Mcl-1 protein stability through Akt/GSK-3 $\beta$, Mcl-1 is transcriptionally up-regulated in response to Akt activation through mTOR signaling and promotes tumor cell survival (Mills et al. 2008). GSK-3 $\beta$ also phosphorylates Bax and induces an activating conformational change, a response that has been shown to be inhibited by Akt in neuronal cells (Linseman et al. 2004) and in yeast (Arokium et al. 2007). Similarly, in $\mathrm{H} 9 \mathrm{c} 2$ cells, $\mathrm{H}_{2} \mathrm{O}_{2}$-induced BAX translocation to mitochondria was attenuated when GSK-3 $\beta$ was knocked down by siRNA or when cells were stimulated with erythropoietin, an Akt agonist (Ohori et al. 2008). It has also been reported that GSK-3 inhibitor treatment increases the association of Bcl-2 with mitochondria in the heart (Das et al. 2008). Taken together, there are a multitude of possible mechanisms through which GSK-3 $\beta$ could 
mediate the protective effects of Akt on cell survival in the heart.

\section{Hexokinase-II and Akt mediated mitochondrial protection}

Hexokinase (HK) catalyzes the first step of glycolysis, phosphorylating glucose to glucose-6-phosphate, and is therefore of fundamental importance in cellular metabolism and physiology. There are four isoforms of HK (I, II, III and IV). HK-I and HK-II have mitochondrial binding motifs at their N-terminus and are reported to bind to the outer mitochondrial membrane through VDAC (Anflous-Pharayra et al. 2007; Azoulay-Zohar et al. 2004; Nakashima et al. 1986; Pastorino et al. 2005). HK-I is ubiquitously expressed and HK-II, while also widely expressed, is the predominant isoform in insulin sensitive tissues such as adipose, skeletal and cardiac muscle and in most cancer cells (Pastorino and Hoek 2003; Wilson 2003). Pedersen's laboratory has suggested that mitochondrial HKs play a role in facilitating ATP production through the preferential access of this enzyme to ATP generated by mitochondria, resulting in more efficient glycolysis (Mathupala et al. 2006; Pedersen 2007). Elevated glycolysis even in the presence of oxygen is one of the hallmark changes in metabolism associated with cancer cells, and was classically described as the Warburg Effect (Pastorino and Hoek 2003; Pedersen 2007).

There is increasing evidence that energy metabolism and cell survival utilize common pathways in many organ systems, and key amongst these is the recognition that Akt regulates metabolism as well as cell survival (Matsui and Rosenzweig 2005; Pastorino and Hoek 2003). Aktmediated protection of cardiomyocytes against $\mathrm{I} / \mathrm{R}$ is accompanied by enhanced sarcolemmal Glut- 4 expression and glucose uptake (Matsui et al. 2001). Glyceraldehyde-3phosphate dehydrogenase (GAPDH), a glycolytic enzyme, mediates not only changes in glycolysis but also protects cells from caspase-independent cell death (CICD) by enhancing autophagy (Colell et al. 2007). Of further interest, the apoptotic and metabolic machinery share certain signaling molecules (Galluzzi et al. 2008). For instance, a physiological/metabolic role of the proapoptotic Bcl-2 family protein BAD has been revealed in pancreatic beta cells in which phosphorylation of BAD at Ser155 inhibits its apoptotic effect but concomitantly increases glucose-fueled mitochondrial respiration (Danial et al. 2008). This increase in mitochondrial metabolism enhances glucose-stimulated insulin secretion from the beta cells by a mechanism that involves binding and stimulation of glucokinase (the HK IV isoform mainly expressed in pancreas and liver) by phosphorylated BAD (Danial et al.
2008). Whether a similar mechanism for maintenance of optimal glucose metabolism in heart could be mediated through an interaction of phosphorylated BAD with hexokinase II is not yet known.

Mitochondrial HK-II and the pro-survival effect

There is accumulating evidence that HKs play a role in protective as well as glycolytic signaling. Treatment of cells with heparin-binding epidermal growth factor (HB-EGF) increases cellular HK activity in renal epithelial cells and expression of HK-I by adenovirus protects against acute oxidant-induced epithelial cell death (Bryson et al. 2002). Similarly, retroviral overexpression of HK-II in lung epithelial-like A549 cells is protective against oxidative injury and this overexpressed HK-II is localized to mitochondria (Ahmad et al. 2002). There is also evidence for HK protection in experiments with isolated mitochondria. Addition of purified mammalian HK-I to mitochondria from rat liver, which do not express mitochondriaassociated $\mathrm{HKs}$, was shown to prevent $\mathrm{Ca}^{2+}$-induced mitochondrial swelling and cytochrome $\mathrm{c}$ release. In contrast addition of yeast HK lacking the ability to bind to mitochondria was not protective (Azoulay-Zohar et al. 2004). These data indicate that mitochondrial HKs have an inhibitory effect on $\mathrm{Ca}^{2+}$-induced PT-pore opening. Support for a role of endogenous HKs in protection comes from the observation that dissociation of HK-II from mitochondria sensitizes fibroblast to apoptotic death (Majewski et al. 2004a) and induces apoptosis in Hela cells through a PTpore opening (Chiara et al. 2008). Taken together, these results provide support for the idea that mitochondrial HK-I and HK-II have the ability to protect mitochondria against ROS or $\mathrm{Ca}^{2+}$ overload, two well-known PT-pore inducers. HK-II also protects against apoptosis induced by Bcl-2 family proteins such as Bax by competitive inhibition of Bax binding to VDAC (Majewski et al. 2004a; Pastorino and Hoek 2003; Pastorino et al. 2002; Robey and Hay 2006).

The role of HK-II in cardioprotection has not been fully considered although HK-II is abundantly expressed in the heart. Several recent studies have demonstrated a protective role of mitochondrial HKs in cardiomyocytes (Chiara et al. 2008; Miyamoto et al. 2008; Sun et al. 2008). Overexpression of full length HK-I or HK-II was shown to protect against $\mathrm{H}_{2} \mathrm{O}_{2}$-induced mitochondrial depolarization in neonatal rat ventricular myocytes (NRVMs) (Sun et al. 2008). Decreased protection was observed using either mutants lacking the mitochondrial binding motif or kinasedead HK-I or HK-II (Sun et al. 2008), implicating mitochondrial binding and the catalytic activity of hexokinase in protection of NRVMs. Chiara et al. (2008) demonstrated that dissociation of mitochondrial HK-II 
increases susceptibility of adult ventricular myocytes to ROS induced PT-pore opening (Chiara et al. 2008). Our work was the first to report that HK-II is phosphorylated by Akt and plays a significant role in Akt-mediated protection against $\mathrm{Ca}^{2+}$ overload in isolated heart mitochondria and against $\mathrm{H}_{2} \mathrm{O}_{2}$-induced injury of NRVMs (Miyamoto et al. 2008), as described below.

Mitochondrial HKs and Akt mediated protection

The protective effect of mitochondrial HK-II has been linked to the PI3K/Akt signaling axis (Gottlob et al. 2001; Majewski et al. 2004a; Pastorino and Hoek 2003; Pastorino et al. 2002; Rathmell et al. 2003; Robey and Hay 2006). Hay and co-workers demonstrated that expression of membrane targeted constitutively activated Akt (myristoylated-Akt; myr-Akt) increased mitochondrial HK activity in Ratla fibroblasts and suggested that HK was involved in Akt-mediated cell survival (Gottlob et al. 2001). Cells were protected against growth factor withdrawal and UV exposure, and adenoviral HK-I expression mimicked the protective ability of myr-Akt. It has also been shown that Akt inhibits tBid-induced apoptosis through increased mitochondrial HK activity, antagonizing tBID-mediated BAX and BAK activation at mitochondria (Majewski et al. 2004b). Interestingly, disruption of mitochondrial HK-II association impaired myr-Akt-mediated protection even in the absence of Bax and Bak, critical mediators of MOMP. This strongly suggests that Akt/mitochondrial HK-II has the ability to prevent cell death induced by mechanisms beyond those that regulate Bcl-2 family proteins and MOMP.

Recent work from our laboratory suggested that mitochondrial HK-II plays a crucial role in Akt-mediated inhibition of the PT-pore in cardiomyocytes (Miyamoto et al. 2008). In our study, endogenous Akt was activated by LIF, shown to accumulate at mitochondria and implicated in phosphorylation of mitochondrial HK-II. HK-II has an Akt consensus sequence $(\mathrm{RxRxxS} / \mathrm{T})$ that is conserved in rat, mouse and human. The appearance of phosphorylated Akt at mitochondria was associated with increased mitochondrial HK-II. Dissociation of HK-II from mitochondria diminished the protective effects of LIF against $\mathrm{H}_{2} \mathrm{O}_{2}$ induced mitochondrial depolarization in NRVMs. Addition of recombinant active Akt to mitochondria isolated from adult mouse heart inhibited $\mathrm{Ca}^{2+}$-induced cytochrome $\mathrm{c}$ release and this effect was reversed by dissociation of HKII from the mitochondria. Thus phosphorylation of mitochondrial HK-II appears to underly Akt-mediated PT-pore inhibition in cardiomyocytes. A similar observation was recently reported in Hela cells where insulin, a strong Akt activating agonist that normally prevents cell death, was unable to antagonize cell death induced by HK-II dissociation from mitochondria (Chiara et al. 2008). These results provide strong support for the idea that mitochondrial HK-II is a critical effector of Akt-mediated mitochondrial protection.

It is of interest that mitochondrial HK activity in the heart is increased by interventions known to activate Akt, including insulin, preconditioning and morphine (Russell et al. 1992; Zuurbier et al. 2005), although conflicting data has been shown (Doenst et al. 1998). An immunogold labeling study further demonstrated that insulin increases mitochondrial association of HK-I and HK-II and the finding that the increase is greater for HK-II than HK-I suggested differential regulation of distribution of these two mitochondrial HKs (Southworth et al. 2007). This is of particular interest as we found that there is an Akt phosphorylation consensus sequence in mouse, rat and human HK-II but not in HK-I (or HK-III). Thus Aktmediated phosphorylation and regulation of hexokinase distribution might be specific to HK-II. It will be of interest to investigate whether the Akt/HK-II pathway plays a significant role in preservation of heart integrity against stress such as ischemia/reperfusion in vivo.

There is evidence that Akt also regulates the expression of HK-II at the transcriptional level. Insulin treatment was shown to increase HK-II mRNA in adipose and skeletal muscle cell lines (Printz et al. 1993). A subsequent study by the same group showed that insulin induced upregulation of HK-II but not HK-I and this induction of HK-II was inhibited by PI3K blockers or rapamycin, suggesting a contribution of PI3K/Akt and mTOR to induction of HK-II mRNA by insulin (Osawa et al. 1996). Similar observations were reported by other groups examining the effect of insulin in 3T3-L1 adipocytes (Culbert and Tavare 2002) and colony-stimulating factor-1 in myeloid cells (Lee and States 2006). We also observed that HK-II protein expression is increased in NRVMs in response to $48 \mathrm{~h}$ LIF treatment or overexpression of wild-type Akt (unpublished observation), consistent with a role for Akt in HK-II upregulation in the heart. Thus, in addition to acute regulation of mitochondrial HK-II through phosphorylation, the upregulation of HK-II induced by Akt activation may contribute to protective effects of Akt under chronic stress.

How does mitochondrial HK-II prevent PT-pore opening?

Although protective roles of mitochondrial HKs have been clearly demonstrated, the mechanism by which mitochondrial HK-I and HK-II protect mitochondria are not clear. Mitochondrial HK has preferential access to ATP generated by mitochondria and the ADP produced by this reaction can be transported back into mitochondria by the ANT and used as a substrate by $\mathrm{F}_{1} \mathrm{~F}_{0}$ ATP synthase to produce ATP (ADP recycling). By providing mitochondria with a constant supply of ADP (presuming an adequate supply of inorganic 
phosphate), mitochondria can slightly depolarize the membrane and can thus minimize ROS production by the electron transport chain (da-Silva et al. 2004). This could contribute to protection, although this needs to be experimentally proven especially under stressed conditions. In fact, apoptosis induced by HK-II detachment from mitochondria was prevented by deletion or inhibition of Cyp-D or inhibition of the ANT, but not by an $\mathrm{F}_{1} \mathrm{~F}_{0}$ ATP synthase inhibitor (Chiara et al. 2008). While VDAC is an established binding partner of HK-II at the OMM, it has been shown using VDAC KO MEF cells that VDAC is not involved in apoptosis induced by HK-II dissociation (Chiara et al. 2008).

Interestingly, pharmacological inhibition or knockdown of Cyp-D resulted in release of HK-II from mitochondria (Chiara et al. 2008; Machida et al. 2006), suggesting that Cyp-D stabilizes mitochondrial HK-II binding. Cyp-D and HK-II have both been postulated to be regulatory components of the PT-pore. Gene deletion of Cyp-D blocks PTpore opening and conversely overexpression of Cyp-D induces mitochondrial swelling and cell death in the heart (Baines et al. 2005). In contrast to the stimulatory role of Cyp-D in PT-pore induction in the heart, mitochondrial HKs play an inhibitory role in PT-pore opening. These positive and negative regulators appear to interact with each other to regulate pore opening. However, it remains unclear which molecule(s) mediate the interaction of these two PTpore regulators. Cyp-D is a mitochondrial matrix protein and HK-II binds to the OMM thus it is unlikely that they physically interact. Cyp-D and HK-II bind to ANT and VDAC respectively, but the recent exclusion of these proteins as necessary for PT-pore opening clearly suggests that other proteins must be involved in HK-II and CypDmediated protection. Recent data suggests that the phosphate carrier binds to $\mathrm{CypD}$, and this inner membrane transporter has been implicated in formation of the PT pore (Alcala et al. 2008; Leung et al. 2008). As well, phosphate has recently been shown to be required for inhibition of PTpore formation by $\mathrm{CsA}$ or by $\mathrm{CypD}$ ablation (Basso et al. 2008), which may imply regulation of phosphate carrier conformation by the presence of its substrate. Recently, Cyp$\mathrm{D}$ was suggested to directly bind to Bcl-2 (Eliseev et al. 2009), which would require Bcl-2 to be localized to and span the inner membrane. New avenues of exploration will need to be pursued to identify the full complement of proteins involved in HK-II-mediated protection of mitochondria.

\section{Upstream of mitochondrial PT-pore formation: Inhibition of cytosolic $\mathrm{Ca}^{2+}$ overload by Akt}

Cytosolic $\mathrm{Ca}^{2+}$ concentration is tightly regulated such that the intracellular $\mathrm{Ca}^{2+}$ concentration is kept at $100 \mathrm{nM} \sim$ $1 \mu \mathrm{M}$, one to ten thousands fold lower than that in the extracellular space. Dysregulation of $\mathrm{Ca}^{2+}$ handling leads to cytosolic $\mathrm{Ca}^{2+}$ overload, followed by excessive mitochon-

Fig. 1 Akt preserves mitochondrial integrity against stress through multiple target molecules in the heart

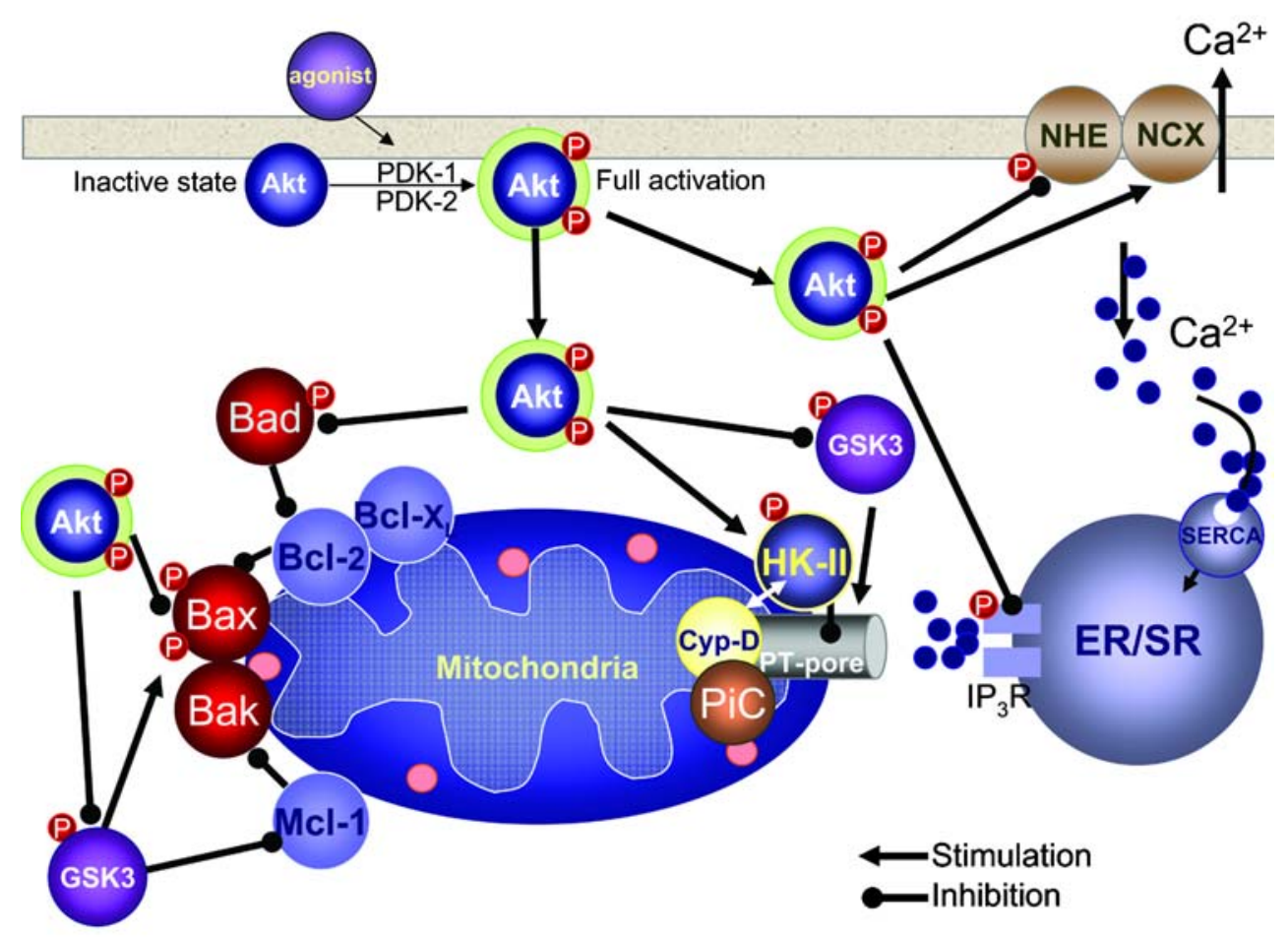


drial $\mathrm{Ca}^{2+}$ sequestration and PT-pore opening. Akt appears able to prevent $\mathrm{Ca}^{2+}$ overloading under pathophysiological settings. For instance, we have found that LIF pre-treatment dramatically dampens the increase in cytoplasmic $\mathrm{Ca}^{2+}$ in NRVMs treated with $\mathrm{H}_{2} \mathrm{O}_{2}$ (unpublished observation), and we previously reported that myr-Akt expression in NRVMs reversed the decrease in expression of $\mathrm{Na}^{+} / \mathrm{Ca}^{2+}$ exchanger1 (NCX1) induced by constitutively active Gq $\alpha$ (Q209L) expression. $\mathrm{NCX} 1$ is responsible for $\mathrm{Ca}^{2+}$ extrusion from the cytoplasm in cardiomyocytes. Akt-mediated preservation of NCX1 expression prevents cytoplasmic $\mathrm{Ca}^{2+}$ overload, opening of the PT-pore and apoptosis induced by Q209L(Miyamoto et al. 2005). Akt-mediated transcriptional up-regulation of NCX1 and NCX3 has recently also been reported in a study on $\mathrm{PC} 12$ cells which further supports the idea that enhanced $\mathrm{Ca}^{2+}$ extrusion via $\mathrm{NCX}$ contributes to Akt-mediated protection (Formisano et al. 2008). Interestingly, the cardiac $\mathrm{Na}^{+} / \mathrm{H}^{+}$exchanger (NHE) has been discovered to be phosphorylated by Akt leading to inhibition of its activity (Snabaitis et al. 2008). NHE imports $\mathrm{Na}^{+}$ions and exports $\mathrm{H}^{+}$ions in response to acidosis during ischemia. The resultant intracellular accumulation of $\mathrm{Na}^{+}$ions, in turn, reverses NCX ion transport to the $\mathrm{Ca}^{2+}$ import mode, leading to cytosolic $\mathrm{Ca}^{2+}$ overloading. NHE inhibition during $\mathrm{I} / \mathrm{R}$ has been established to be protective in many experimental models (Avkiran et al. 2008) and NHE phosphorylation and inhibition mediated by Akt would provide a molecular mechanism for prevention of cytoplasmic $\mathrm{Ca}^{2+}$ overloading in the heart.

Another interesting new finding is that Akt phosphorylates type-I $\mathrm{IP}_{3}$ receptors $\left(\mathrm{IP}_{3} \mathrm{R}\right)$ which inhibits $\mathrm{Ca}^{2+}$ release from the ER and prevents $\mathrm{Ca}^{2+}$ induced apoptosis in non-cardiac cells (Khan et al. 2006; Szado et al. 2008). A consensus sequence for Akt phosphorylation $(\mathrm{RxRxxS} / \mathrm{T})$ is present in all three types of $\mathrm{IP}_{3}$ Rs. Although the contribution of $\mathrm{IP}_{3} \mathrm{Rs}$ to cardiac $\mathrm{Ca}^{2+}$ regulation has been thought to be minimal, there is compelling evidence that $\mathrm{Ca}^{2+}$ release from $\mathrm{IP}_{3} \mathrm{Rs}$ can regulate cardiac cellular functions including positive inotropy, gene expression, induction of arrhythmia and regulation of pacemaking (Domeier et al. 2008; Kockskamper et al. 2008; Roderick and Bootman 2007; Woodcock et al. 2008; Wu et al. 2006). Therefore, it is probable that $\mathrm{IP}_{3}$-induced $\mathrm{Ca}^{2+}$ release plays a role in regulation of mitochondrial $\mathrm{Ca}^{2+}$, as observed in NRVMs stimulated with ATP (Jaconi et al. 2000) and in the heart (Garcia-Perez et al. 2008). ER/SR $\mathrm{Ca}^{2+}$ overloading has been receiving increasing attention in the context of regulation of cell death, since ER/SR $\mathrm{Ca}^{2+}$ pools communicate with mitochondria due to the proximity of release site and mitochondria (Diwan et al. 2008; Garcia-Perez et al. 2008; Jaconi et al. 2000; Szalai et al. 1999). Notably, $\mathrm{IP}_{3} \mathrm{R}$ expression is increased in heart disease (Go et al. 1995), thus IP3R signaling and its regulation by Akt may have increased importance in regulation of mitochondrial $\mathrm{Ca}^{2+}$ and cardiomyocyte survival under pathophysiological conditions. Finally, it is becoming clear that Bcl-2 family proteins not only function at mitochondria but also localize to and control the $\mathrm{Ca}^{2+}$ content of intracellular $\mathrm{Ca}^{2+}$ pools (Pinton and Rizzuto 2006). Apoptotic Bcl-2 family members such as Bax, Bak and Nix localize at ER/SR and increase their $\mathrm{Ca}^{2+}$ content, resulting in large increases in $\mathrm{Ca}^{2+}$ release and subsequent mitochondrial $\mathrm{Ca}^{2+}$ overloading (Demaurex and Distelhorst 2003; Diwan et al. 2008; Nutt et al. 2002; Scorrano et al. 2003). In contrast, anti-apoptotic Bcl-2 family proteins decrease ER $\mathrm{Ca}^{2+}$ content and $\mathrm{Ca}^{2+}$ release (Demaurex and Distelhorst 2003; Palmer et al. 2004). It will be of considerable interest to determine whether Bcl-2 family proteins play a role in SRmitochondrial $\mathrm{Ca}^{2+}$ crosstalk in the heart, as demonstrated in Nix mediated cardiac cell death (Diwan et al. 2008), and whether Akt-mediated phosphorylation of Bcl-2 family proteins can lead to change in their ER/SR localization.

\section{Conclusion}

Akt provides a strong survival signal in various cell types including cardiomyocytes and exerts its protective effects through phosphorylation of diverse target molecules such as Bcl-2 family proteins, GSK-3 $\beta$ and, as recently demonstrated HK-II (Fig. 1). Preservation of mitochondrial integrity is critical for regulation of metabolism and cell survival, and recent compelling evidence indicates that Akt can serve as an integrator and gatekeeper of both of these mitochondrial functions.

Acknowledgements This manuscript was supported by National Institutes of Health Grant HL28143 and HL085577 (to J. H. B.) and American Heart Association Scientist Development Grant 930237N (to S. M.).

Open Access This article is distributed under the terms of the Creative Commons Attribution Noncommercial License which permits any noncommercial use, distribution, and reproduction in any medium, provided the original author(s) and source are credited.

\section{References}

Adams JW, Pagel AL, Means CK, Oksenberg D, Armstrong RC, Brown JH (2000) Circ Res 87:1180-1187

Ahmad A, Ahmad S, Schneider BK, Allen CB, Chang LY, White CW (2002) Am J Physiol Lung Cell Mol Physiol 283:L573-584

Ahmad N, Wang Y, Haider KH, Wang B, Pasha Z, Uzun O, Ashraf M (2006) Am J Physiol Heart Circ Physiol 290:H2402-2408

Aikawa R, Nawano M, Gu Y, Katagiri H, Asano T, Zhu W, Nagai R, Komuro I (2000) Circulation 102:2873-2879

Alcala S, Klee M, Fernandez J, Fleischer A, Pimentel-Muinos FX (2008) Oncogene 27:44-54 
Anflous-Pharayra K, Cai ZJ, Craigen WJ (2007) Biochim Biophys Acta 1767:136-142

Arokium H, Ouerfelli H, Velours G, Camougrand N, Vallette FM, Manon S (2007) J Biol Chem 282:35104-35112

Avkiran M, Cook AR, Cuello F (2008) Curr Opin Pharmacol 8:133-140

Azoulay-Zohar H, Israelson A, Abu-Hamad S, Shoshan-Barmatz V (2004) Biochem J 377:347-355

Baines CP, Kaiser RA, Purcell NH, Blair NS, Osinska H, Hambleton MA, Brunskill EW, Sayen MR, Gottlieb RA, Dorn GW, Robbins J, Molkentin JD (2005) Nature 434:658-662

Baines CP, Kaiser RA, Sheiko T, Craigen WJ, Molkentin JD (2007) Nat Cell Biol 9:550-555

Basso E, Petronilli V, Forte MA, Bernardi P (2008) J Biol Chem 283:26307-26311

Bell RM, Yellon DM (2003) J Mol Cell Cardiol 35:185-193

Bijur GN, Jope RS (2003) J Neurochem 87:1427-1435

Brocheriou V, Hagege AA, Oubenaissa A, Lambert M, Mallet VO, Duriez M, Wassef M, Kahn A, Menasche P, Gilgenkrantz H (2000) J Gene Med 2:326-333

Brunet A, Bonni A, Zigmond MJ, Lin MZ, Juo P, Hu LS, Anderson MJ, Arden KC, Blenis J, Greenberg ME (1999) Cell 96:857-868

Bryson JM, Coy PE, Gottlob K, Hay N, Robey RB (2002) J Biol Chem 277:11392-11400

Camper-Kirby D, Welch S, Walker A, Shiraishi I, Setchell KD, Schaefer E, Kajstura J, Anversa P, Sussman MA (2001) Circ Res 88:1020-1027

Ceci M, Gallo P, Santonastasi M, Grimaldi S, Latronico MV, Pitisci A, Missol-Kolka E, Scimia MC, Catalucci D, Hilfiker-Kleiner D, Condorelli G (2007) Cell Death Differ 14:1060-1062

Chen M, Won DJ, Krajewski S, Gottlieb RA (2002) J Biol Chem 277:29181-29186

Chen Z, Chua CC, Ho YS, Hamdy RC, Chua BH (2001) Am J Physiol Heart Circ Physiol 280:H2313-2320

Chesley A, Lundberg MS, Asai T, Xiao RP, Ohtani S, Lakatta EG, Crow MT (2000) Circ Res 87:1172-1179

Chiara F, Castellaro D, Marin O, Petronilli V, Brusilow WS, Juhaszova M, Sollott SJ, Forte M, Bernardi P, Rasola A (2008) PLoS ONE 3:e1852

Cohen MV, Downey JM (2008) Basic Res Cardiol 103:203-215

Colell A, Ricci JE, Tait S, Milasta S, Maurer U, Bouchier-Hayes L, Fitzgerald P, Guio-Carrion A, Waterhouse NJ, Li CW, Mari B, Barbry P, Newmeyer DD, Beere HM, Green DR (2007) Cell 129:983-997

Cook SA, Matsui T, Li L, Rosenzweig A (2002) J Biol Chem 277:22528-22533

Craig R, Wagner M, McCardle T, Craig AG, Glembotski CC (2001) J Biol Chem 276:37621-37629

Crompton M (1999) Biochem J 341(Pt 2):233-249

Crompton M, Ellinger H, Costi A (1988) Biochem J 255:357-360

Crow MT, Mani K, Nam YJ, Kitsis RN (2004) Circ Res 95:957-970

Culbert AA, Tavare JM (2002) Biochim Biophys Acta 1578:43-50

Danial NN, Walensky LD, Zhang CY, Choi CS, Fisher JK, Molina AJ, Datta SR, Pitter KL, Bird GH, Wikstrom JD, Deeney JT, Robertson K, Morash J, Kulkarni A, Neschen S, Kim S, Greenberg ME, Corkey BE, Shirihai OS, Shulman GI, Lowell BB, Korsmeyer SJ (2008) Nat Med 14:144-153

Das S, Wong R, Rajapakse N, Murphy E, Steenbergen C (2008) Circ Res da-Silva WS, Gomez-Puyou A, de Gomez-Puyou MT, Moreno-Sanchez R, De Felice FG, de Meis L, Oliveira MF, Galina A (2004) J Biol Chem 279:39846-39855

Datta SR, Dudek H, Tao X, Masters S, Fu H, Gotoh Y, Greenberg ME (1997) Cell 91:231-241

Davidson SM, Hausenloy D, Duchen MR, Yellon DM (2006) Int J Biochem Cell Biol 38:414-419

del Peso L, Gonzalez-Garcia M, Page C, Herrera R, Nunez G (1997) Science 278:687-689
Demaurex N, Distelhorst C (2003) Science 300:65-67

Dijkers PF, Medema RH, Lammers JW, Koenderman L, Coffer PJ (2000) Curr Biol 10:1201-1204

Diwan A, Matkovich SJ, Yuan Q, Zhao W, Yatani A, Brown JH, Molkentin JD, Kranias EG, Dorn GW, 2nd (2008) J Clin Invest

Doenst T, Han Q, Goodwin GW, Guthrie PH, Taegtmeyer H (1998) Am J Physiol 275:E558-567

Domeier TL, Zima AV, Maxwell JT, Huke S, Mignery GA, Blatter LA (2008) Am J Physiol Heart Circ Physiol 294:H596-604

Dorn GW 2nd, Brown JH (1999) Trends Cardiovasc Med 9:26-34

Downey JM, Davis AM, Cohen MV (2007) Heart Fail Rev 12:181-188

Dyall SD, Brown MT, Johnson PJ (2004) Science 304:253-257

Eliseev RA, Malecki J, Lester T, Zhang Y, Humpfrey J, Gunter TE (2009) J Biol Chem

Fan GC, Zhou X, Wang X, Song G, Qian J, Nicolaou P, Chen G, Ren X, Kranias EG (2008) Circ Res 103:1270-1279

Formisano L, Saggese M, Secondo A, Sirabella R, Vito P, Valsecchi V, Molinaro P, Di Renzo G, Annunziato L (2008) Mol Pharmacol 73:727-737

Fujio Y, Nguyen T, Wencker D, Kitsis RN, Walsh K (2000) Circulation 101:660-667

Galluzzi L, Joza N, Tasdemir E, Maiuri MC, Hengartner M, Abrams JM, Tavernarakis N, Penninger J, Madeo F, Kroemer G (2008) Cell Death Differ 15:1113-1123

Garcia-Perez C, Hajnoczky G, Csordas G (2008) J Biol Chem 283:32771-32780

Gardai SJ, Hildeman DA, Frankel SK, Whitlock BB, Frasch SC, Borregaard N, Marrack P, Bratton DL, Henson PM (2004) J Biol Chem 279:21085-21095

Gilley J, Coffer PJ, Ham J (2003) J Cell Biol 162:613-622

Go LO, Moschella MC, Watras J, Handa KK, Fyfe BS, Marks AR (1995) J Clin Invest 95:888-894

Gomez L, Paillard M, Thibault H, Derumeaux G, Ovize M (2008) Circulation 117:2761-2768

Gottlob K, Majewski N, Kennedy S, Kandel E, Robey RB, Hay N (2001) Genes Dev 15:1406-1418

Green DR (2005) Cell 121:671-674

Green DR, Kroemer G (2004) Science 305:626-629

Gustafsson AB, Gottlieb RA (2008) Cardiovasc Res 77:334-343

Gustafsson AB, Gottlieb RA (2003) J Clin Immunol 23:447-459

Halestrap AP, Pasdois P (2009) Biochim Biophys Acta

Havasi A, Li Z, Wang Z, Martin JL, Botla V, Ruchalski K, Schwartz JH, Borkan SC (2008) J Biol Chem 283:12305-12313

Hayakawa Y, Chandra M, Miao W, Shirani J, Brown JH, Dorn GW 2nd, Armstrong RC, Kitsis RN (2003) Circulation 108:30363041

Hirotani S, Zhai P, Tomita H, Galeotti J, Marquez JP, Gao S, Hong C, Yatani A, Avila J, Sadoshima J (2007) Circ Res 101:1164-1174

Hochhauser E, Kivity S, Offen D, Maulik N, Otani H, Barhum Y, Pannet H, Shneyvays V, Shainberg A, Goldshtaub V, Tobar A, Vidne BA (2003) Am J Physiol Heart Circ Physiol 284:H23512359

Jaconi M, Bony C, Richards SM, Terzic A, Arnaudeau S, Vassort G, Puceat M (2000) Mol Biol Cell 11:1845-1858

Jin ZQ, Zhou HZ, Zhu P, Honbo N, Mochly-Rosen D, Messing RO, Goetzl EJ, Karliner JS, Gray MO (2002) Am J Physiol Heart Circ Physiol 282:H1970-1977

Jonassen AK, Sack MN, Mjos OD, Yellon DM (2001) Circ Res 89:1191-1198

Juhaszova M, Zorov DB, Kim SH, Pepe S, Fu Q, Fishbein KW, Ziman BD, Wang S, Ytrehus K, Antos CL, Olson EN, Sollott SJ (2004) J Clin Invest 113:1535-1549

Khan MT, Wagner L 2nd, Yule DI, Bhanumathy C, Joseph SK (2006) J Biol Chem 281:3731-3737

Kockskamper J, Zima AV, Roderick HL, Pieske B, Blatter LA, Bootman MD (2008) J Mol Cell Cardiol 45:128-147 
Kokoszka JE, Waymire KG, Levy SE, Sligh JE, Cai J, Jones DP, MacGregor GR, Wallace DC (2004) Nature 427:461-465

Konishi H, Matsuzaki H, Tanaka M, Takemura Y, Kuroda S, Ono Y, Kikkawa U (1997) FEBS Lett 410:493-498

Kroemer G, Galluzzi L, Brenner C (2007) Physiol Rev 87:99-163

Kubli DA, Ycaza JE, Gustafsson AB (2007) Biochem J 405:407-415

Kunkel MT, Ni Q, Tsien RY, Zhang J, Newton AC (2005) J Biol Chem 280:5581-5587

Kuwahara K, Saito Y, Kishimoto I, Miyamoto Y, Harada M, Ogawa E, Hamanaka I, Kajiyama N, Takahashi N, Izumi T, Kawakami R, Nakao K (2000) J Mol Cell Cardiol 32:1385-1394

Lai HC, Liu TJ, Ting CT, Sharma PM, Wang PH (2003) Mol Cell Endocrinol 205:99-106

Lee AW, States DJ (2006) Cell Death Differ 13:1900-1914

Leung AW, Varanyuwatana P, Halestrap AP (2008) J Biol Chem 283:26312-26323

Linseman DA, Butts BD, Precht TA, Phelps RA, Le SS, Laessig TA, Bouchard RJ, Florez-McClure ML, Heidenreich KA (2004) J Neurosci 24:9993-10002

Maack C, O'Rourke B (2007) Basic Res Cardiol 102:369-392

Machida K, Ohta Y, Osada H (2006) J Biol Chem 281:1431414320

Majewski N, Nogueira V, Bhaskar P, Coy PE, Skeen JE, Gottlob K, Chandel NS, Thompson CB, Robey RB, Hay N (2004a) Mol Cell 16:819-830

Majewski N, Nogueira V, Robey RB, Hay N (2004b) Mol Cell Biol 24:730-740

Mathupala SP, Ko YH, Pedersen PL (2006) Oncogene 25:4777-4786

Matsuda T, Zhai P, Maejima Y, Hong C, Gao S, Tian B, Goto K, Takagi H, Tamamori-Adachi M, Kitajima S, Sadoshima J (2008) Proc Natl Acad Sci U S A 105:20900-20905

Matsui T, Li L, del Monte F, Fukui Y, Franke TF, Hajjar RJ, Rosenzweig A (1999) Circulation 100:2373-2379

Matsui T, Rosenzweig A (2005) J Mol Cell Cardiol 38:63-71

Matsui T, Tao J, del Monte F, Lee KH, Li L, Picard M, Force TL, Franke TF, Hajjar RJ, Rosenzweig A (2001) Circulation 104:330-335

Maurer U, Charvet C, Wagman AS, Dejardin E, Green DR (2006) Mol Cell 21:749-760

Means CK, Xiao CY, Li Z, Zhang T, Omens JH, Ishii I, Chun J, Brown JH (2007) Am J Physiol Heart Circ Physiol 292:H2944-2951

Mehrhof FB, Muller FU, Bergmann MW, Li P, Wang Y, Schmitz W, Dietz R, von Harsdorf R (2001) Circulation 104:2088-2094

Menon B, Johnson JN, Ross RS, Singh M, Singh K (2007) J Mol Cell Cardiol 42:653-661

Mills JR, Hippo Y, Robert F, Chen SM, Malina A, Lin CJ, Trojahn U, Wendel HG, Charest A, Bronson RT, Kogan SC, Nadon R, Housman DE, Lowe SW, Pelletier J (2008) Proc Natl Acad Sci U S A 105:10853-10858

Miyamoto S, Howes AL, Adams JW, Dorn GW 2nd, Brown JH (2005) J Biol Chem 280:38505-38512

Miyamoto S, Murphy AN, Brown JH (2008) Cell Death Differ 15:521-529

Mocanu MM, Bell RM, Yellon DM (2002) J Mol Cell Cardiol 34:661-668

Morisco C, Zebrowski D, Condorelli G, Tsichlis P, Vatner SF, Sadoshima J (2000) J Biol Chem 275:14466-14475

Muraski JA, Rota M, Misao Y, Fransioli J, Cottage C, Gude N, Esposito G, Delucchi F, Arcarese M, Alvarez R, Siddiqi S, Emmanuel GN, Wu W, Fischer K, Martindale JJ, Glembotski CC, Leri A, Kajstura J, Magnuson N, Berns A, Beretta RM, Houser SR, Schaefer EM, Anversa P, Sussman MA (2007) Nat Med 13:1467-1475

Murphy E, Steenbergen C (2008) Physiol Rev 88:581-609

Naga Prasad SV, Esposito G, Mao L, Koch WJ, Rockman HA (2000) J Biol Chem 275:4693-4698
Nakagawa T, Shimizu S, Watanabe T, Yamaguchi O, Otsu K, Yamagata H, Inohara H, Kubo T, Tsujimoto Y (2005) Nature 434:652-658

Nakashima RA, Mangan PS, Colombini M, Pedersen PL (1986) Biochemistry 25:1015-1021

Nakayama H, Chen X, Baines CP, Klevitsky R, Zhang X, Zhang H, Jaleel N, Chua BH, Hewett TE, Robbins J, Houser SR, Molkentin JD (2007) J Clin Invest 117:2431-2444

Nakayama H, Wilkin BJ, Bodi I, Molkentin JD (2006) Faseb J 20:1660-1670

Negoro S, Oh H, Tone E, Kunisada K, Fujio Y, Walsh K, Kishimoto T, Yamauchi-Takihara K (2001) Circulation 103:555-561

Nishihara M, Miura T, Miki T, Tanno M, Yano T, Naitoh K, Ohori K, Hotta H, Terashima Y, Shimamoto K (2007) J Mol Cell Cardiol 43:564-570

Nishino Y, Webb IG, Davidson SM, Ahmed AI, Clark JE, Jacquet S, Shah AM, Miura T, Yellon DM, Avkiran M, Marber MS (2008) Circ Res 103:307-314

Nutt LK, Pataer A, Pahler J, Fang B, Roth J, McConkey DJ, Swisher SG (2002) J Biol Chem 277:9219-9225

Ohori K, Miura T, Tanno M, Miki T, Sato T, Ishikawa S, Horio Y, Shimamoto K (2008) Am J Physiol Heart Circ Physiol 295: H2079-2086

Osawa H, Sutherland C, Robey RB, Printz RL, Granner DK (1996) J Biol Chem 271:16690-16694

Palmer AE, Jin C, Reed JC, Tsien RY (2004) Proc Natl Acad Sci U S A 101:17404-17409

Pap M, Cooper GM (1998) J Biol Chem 273:19929-19932

Pastorino JG, Hoek JB (2003) Curr Med Chem 10:1535-1551

Pastorino JG, Hoek JB, Shulga N (2005) Cancer Res 65:10545-10554

Pastorino JG, Shulga N, Hoek JB (2002) J Biol Chem 277:7610-7618

Pedersen PL (2007) J Bioenerg Biomembr 39:211-222

Pinton P, Rizzuto R (2006) Cell Death Differ 13:1409-1418

Plas DR, Talapatra S, Edinger AL, Rathmell JC, Thompson CB (2001) J Biol Chem 276:12041-12048

Printz RL, Koch S, Potter LR, O’Doherty RM, Tiesinga JJ, Moritz S, Granner DK (1993) J Biol Chem 268:5209-5219

Rathmell JC, Fox CJ, Plas DR, Hammerman PS, Cinalli RM, Thompson CB (2003) Mol Cell Biol 23:7315-7328

Reed JC (2008) Blood 111:3322-3330

Robert P, Tsui P, Laville MP, Livi GP, Sarau HM, Bril A, BerrebiBertrand I (2001) J Mol Cell Cardiol 33:1589-1606

Robey RB, Hay N (2006) Oncogene 25:4683-4696

Roderick HL, Bootman MD (2007) J Physiol 581:883-884

Russell RR 3rd, Mrus JM, Mommessin JI, Taegtmeyer H (1992) J Clin Invest 90:1972-1977

Sarbassov DD, Guertin DA, Ali SM, Sabatini DM (2005) Science 307:1098-1101

Sasaki K, Sato M, Umezawa Y (2003) J Biol Chem 278:3094530951

Scarabelli TM, Knight R, Stephanou A, Townsend P, Chen-Scarabelli C, Lawrence K, Gottlieb R, Latchman D, Narula J (2006) Curr Probl Cardiol 31:181-264

Scorrano L, Oakes SA, Opferman JT, Cheng EH, Sorcinelli MD, Pozzan T, Korsmeyer SJ (2003) Science 300:135-139

Sheng Z, Knowlton K, Chen J, Hoshijima M, Brown JH, Chien KR (1997) J Biol Chem 272:5783-5791

Shioi T, McMullen JR, Kang PM, Douglas PS, Obata T, Franke TF, Cantley LC, Izumo S (2002) Mol Cell Biol 22:2799-2809

Shiojima I, Walsh K (2006) Genes Dev 20:3347-3365

Skurk C, Izumiya Y, Maatz H, Razeghi P, Shiojima I, Sandri M, Sato K, Zeng L, Schiekofer S, Pimentel D, Lecker S, Taegtmeyer H, Goldberg AL, Walsh K (2005) J Biol Chem 280:20814-20823

Snabaitis AK, Cuello F, Avkiran M (2008) Circ Res 103:881-890

Southworth R, Davey KA, Warley A, Garlick PB (2007) Am J Physiol Heart Circ Physiol 292:H378-386 
Sun L, Shukair S, Naik TJ, Moazed F, Ardehali H (2008) Mol Cell Biol 28:1007-1017

Szado T, Vanderheyden V, Parys JB, De Smedt H, Rietdorf K, Kotelevets L, Chastre E, Khan F, Landegren U, Soderberg O, Bootman MD, Roderick HL (2008) Proc Natl Acad Sci U S A 105:2427-2432

Szalai G, Csordas G, Hantash BM, Thomas AP, Hajnoczky G (2000) J Biol Chem 275:15305-15313

Szalai G, Krishnamurthy R, Hajnoczky G (1999) Embo J 18:63496361

Tanveer A, Virji S, Andreeva L, Totty NF, Hsuan JJ, Ward JM, Crompton M (1996) Eur J Biochem 238:166-172

Tong H, Chen W, Steenbergen C, Murphy E (2000) Circ Res 87:309_ 315

Tong H, Imahashi K, Steenbergen C, Murphy E (2002) Circ Res 90:377-379

Toth A, Jeffers JR, Nickson P, Min JY, Morgan JP, Zambetti GP, Erhardt P (2006) Am J Physiol Heart Circ Physiol 291:H52-60

Uchiyama T, Engelman RM, Maulik N, Das DK (2004) Circulation 109:3042-3049
Webster KA, Graham RM, Bishopric NH (2005) J Mol Cell Cardiol 38:35-45

Weiss JN, Korge P, Honda HM, Ping P (2003) Circ Res 93:292-301

Williams MR, Arthur JS, Balendran A, van der Kaay J, Poli V, Cohen P, Alessi DR (2000) Curr Biol 10:439-448

Wilson JE (2003) J Exp Biol 206:2049-2057

Woodcock EA, Kistler PM, Ju Y (2008) Cardiovasc Res

Wu X, Zhang T, Bossuyt J, Li X, McKinsey TA, Dedman JR, Olson EN, Chen J, Brown JH, Bers DM (2006) J Clin Invest 116:675682

Yamaguchi H, Wang HG (2001) Oncogene 20:7779-7786

Yussman MG, Toyokawa T, Odley A, Lynch RA, Wu G, Colbert MC, Aronow BJ, Lorenz JN, Dorn GW 2nd (2002) Nat Med 8:725730

Zhu WZ, Zheng M, Koch WJ, Lefkowitz RJ, Kobilka BK, Xiao RP (2001) Proc Natl Acad Sci U S A 98:1607-1612

Zorov DB, Juhaszova M, Sollott SJ (2006) Biochim Biophys Acta 1757:509-517

Zuurbier CJ, Eerbeek O, Meijer AJ (2005) Am J Physiol Heart Circ Physiol 289:H496-499 